\title{
Reflections on the City of Alexandria and the growth of the early Christian faith
}

\author{
Angelo Nicolaides \\ Department of Philosophy and Applied Ethics \\ Faculty of Arts, University of Zululand \\ Kwa-Dlangezwa, South Africa \\ University of Zululand, South Africa \\ http//:orcid.org/0000-0002-2153-2853 \\ Doi: https://doi.org/10.46222/pharosjot.10311
}

\begin{abstract}
The city of Alexandria in Egypt was and remains the centre of the Orthodox Patriarchate of Alexandria, and it was one of the major centres of Christianity in the Eastern Roman Empire. St. Mark the Evangelist was the founder of the See, and the Patriarchate's emblem is the Lion of Saint Mark. It was in this city where the Christian faith was vigorously promoted, and in which Hellenic culture flourished. The first theological school of Christendom was established which drove catechesis and the study of religious philosophy to new heights. It was greatly supported in its quest by numerous champions of the faith and early Church Fathers such as inter-alia, Pantaenus, Clement, Dionysius, Gregory, Eusebius, Athanasius, Didymus and Origen. Both the Greek Orthodox Church of Alexandria and also the Coptic Church, lay claim to the ancient legacy of Alexandria. By the time of the Arab conquest of Egypt in $641 \mathrm{CE}$, the city had lost much of its significance. Today the Greek or Eastern Orthodox Patriarchate of Alexandria remains a very important organ the dissemination of Christianity in Africa especially due to its missionary activities. The head bishop of the Patriarchate of Alexandria and all Africa, Theodore II, and his clerics are performing meritorious works on the continent to the glory of God's Kingdom. This article traces, albeit it in a limited sense, the history of the faith in Alexandria using a desk-top research methodology. In order to trace Alexandria's historical development and especially its Christian religious focus, existing relevant primary and secondary data considered to be relevant was utilised including research material published in academic articles, books, bibliographic essays, Biblical and Church documents, electronic documents and websites.
\end{abstract}

Keywords: Alexandria, Christianity, Greek/Eastern Orthodox Church, Hellenism, Patriarchate.

\section{Introduction}

Alexandria was founded in 331 BCE by Alexander the Great, who when he found himself at the western extremity of the Nile Delta at what was called the Isle of Pharos, immediately realised the value of the area in terms of its strategic importance both military and for the promotion of trade. He believed that it could serve as the gateway of his empire through which Hellenism could spread further. It was here that the Pharos, a lighthouse, was erected which became a wonder of the world along with the Great Library which was the largest in the ancient world. Alexandria dominated the intellectual and cultural stage of the ancient Mediterranean for much of the Hellenistic age and into late antiquity, spreading Hellenic civilisation far and wide. Alexander dreamed of a world mastered by Greek culture, but no direct attempt was made to replace the ruling or dominant cultures of the Levant with Greek elements (Price, 1971). 
Alexandria is believed to have been the largest city in the ancient world before Rome surpassed it. Alexander the Great favoured the idea of including in the Greek empire all races in peaceful co-existence and Alexandria was indeed a suitable place to try to promote this vision.

\section{The early city}

Alexander had grand plans for Alexandria and his principal architect for his vision was Dinocrates (Favard-Meeks \& Meeks, 2000). To the east of Alexandria lay a huge marshy area and numerous small islands and from about $7^{\text {th }}$ century BCE, two port towns, namely Canopus and Heracleion served the needs of the population. In addition there existed a town called Menouthis, thus the area was not entirely uninhabited. The founding of such towns demonstrates the importance of the area in the Nile Delta for the purpose of trade by foreigners with Egypt (Favard-Meeks \& Meeks, 2000). The city currently occupied by modern Alexandria was a small town called Rhakotis. Alexander decided to lay out the plans for a new larger city which developed and which was named after him. When Alexander ultimately left the area, he tasked Cleomenes to proceed with the development of the city. When Alexander left the area, he tasked Cleomenes to proceed with the development of the city. A struggle for power ensued on the death of Alexander, and eventually, it was Ptolemy I of Egypt who had Alexander's body returned to the city where his tomb became a touristic attraction (Harris \& Ruffini, 2004). After its foundation, Alexandria became the centre of the Ptolemaic Kingdom, and it very rapidly developed into one of the supreme cities of Hellenism. It was said that only Rome, which expanded its power and controlled Egypt in $30 \mathrm{BCE}$, was greater than Alexandria in terms of its extent and affluence (Mahaffy, 1895). There existed in Alexandria institutions devoted to the conservation and study of inter alia, Hellenic culture, philosophy and science, and this ostensibly initially excluded non-Greeks. It was in especially literature, that non-Greek texts were carefully sanctioned and they were only permitted in the library once they had been translated into Greek (Erskine, 1995).

The intense Hellenistic age extended from 323 BCE to creation of the Roman Empire in 30 CE. The Hellenistic cities established by Alexander and his diadochi or successors, rapidly became commercial and administrative centres and it was in these cities that Greek culture was disseminated (Price, 1971). The city of Alexandria was incredibly cosmopolitan and was developed along the lines of a Greek polis. A simplified dialect of classical Greek called koine or common, was also adopted and intermingling of cultures helped to eliminate the parochialism which was commonplace for many centuries. (Price, 1971). They were of course a large number of indigenous Egyptians in the population as well as many immigrants emanating from all over the world including merchants and these people brought with them their diverse religions and so it was that many gods and goddesses joined the Greek and Egyptian pantheons. For example the god Serapis was a syncretistic entity and had the nature of the Greek God Zeus as well as the Egyptian God or Osiris. This Graeco-Egyptian deity of the Sun was first encountered at Memphis, and his cult was celebrated in association with that of the holy Egyptian bull Apis. Serapis was originally a god of the underworld but was reinstated as a new deity with numerous Hellenic aspects attached to him by Ptolemy I Soter (305-284 BCE), who centred the worship of the god in Alexandria. Serapis was thus imbued with attributes of Zeus, Hades and a range of other Greek deities by the Greeks who hope to unite in worship the races living in the kingdom of the Ptolemies (Price, 1971). The cult even moved into Greek cities such as Athens and Thessalonica.

The Serapeum in Alexandria was the principal and best known of the temples dedicated to Serapis. The cult statue there represented Serapis as a robed and bearded figure regally enthroned, his right hand resting on Cerberus (the three-headed dog who guarded the gate of 
the underworld), while his left hand held an upraised sceptre. Gradually Serapis became revered not only as a Sun god ("Zeus Serapis") but also as a lord of healing and of fertility. The Greeks living near Șaqqārah worshiped the god as Osorapis, which under the Ptolemaic dynasty developed into Serapis, and the temple was termed the Serapeum. "The destruction of the Serapeum at Alexandria by Theophilus, the patriarch of Alexandria, and his followers in $391 \mathrm{CE}$ - together with the obliteration of other pagan temples (all with the encouragement of Emperor Theodosius I) - signalled the final triumph of Christianity not only in Egypt but throughout the Roman Empire" (Kuiper, n.d.).

The Ptolemies sought to keep diverse groups segregated, i.e. Egyptian, Greeks, and Jews. As far as slaves are concerned there is no real evidence relating to them. Scheidel, (cited in Harris and Ruffini), argues that notwithstanding their deficiency in civic status, Egyptians were apparently more numerous than any of the other groups and there is no evidence of a large Jewish community in the third century BCE ( Harris \& Ruffini, 2004). The Greeks of Alexandria placed great importance on the promotion of their Hellenistic culture, and this was done in a sense to exclude and subdue non-Greeks. There were distinct references relating to indigenous Egyptians in Alexandrian poetry and in one such poem, the locals were portrayed as likely assailants (Erskine, 1995). Even Greek law was applied which favoured those of Greek descent (Hirata, 2008). The Ptolemies stressed Greek culture and imbued within the Hellenes of Egypt a unique identity and they 'ran the show so to speak and subjugated their hosts and in the process divided cultures as opposed to uniting them. To press their domination further the Greeks held flamboyant religious pageants in which they demonstrated their power and ethnic superiority (Erskine, 1995) which did not always enthuse other groups. Egyptians for the most part came to be regarded as strangers in their own land and this gave impetus to the later political turmoil under the rule of Ptolemy Philopater the fourth pharaoh of Ptolemaic Egypt (221-204 BCE). Notwithstanding, Hellenism definitely affected the intellectual progress of Jews residing in Alexandria. The blending of Jewish religious teachings with the essence of Hellenism was pronounced so that even the Torah was translated into Greek under Ptolemy II and it was recited in Greek in the synagogues (Schürer, 1912).

At the conclusion of the Fourth Syrian War, a series of revolts transpired in Egypt. The Greek historian Polybius contended that the revolts were due to Ptolemy IV's decision to provide the Egyptians with weapons during the Fourth Syrian War ( Polybius 5.107.1-3). There is also a view that the revolts were perpetrated by disaffected Egyptians mainly emanating from the lower classes who were overtaxed and determined to eliminate the social injustice that existed based on the policies of the Ptolemies (Hölbl, 2001). In fact the revolutionaries captured the city of Thebes in 205 BCE and their leader Horwennefer was crowned as their Pharaoh. His reign in that region lasted until 186 BCE (Hölbl, 2001; Bennett, 2019). To all intents and purposes, Ptolemy IV was not concerned about the Egyptians and was a poor monarch who indulged in opulent ceremonies, totally disregarding the indigenous population and even foreign affairs up to the time of his death (Hölbl, 2001). Ptolemy IV is a foremost character in the deuterocanonical biblical book 3 Maccabees, and he is shown to be an tyrannical leader who contravened divine law by attempting to enter the temple at Jerusalem and then annihilating the Jews by congregating them in the hippodrome at Alexandria where elephants trampled them to death. However, these despicable plans were constantly thwarted by divine intervention and finally Ptolemy IV withdrew his plans and gave privileges to the Jews (Clayton Croy, 2006).

Alexandria was the home of the main Jewish community in the ancient world dating from the foundation of the city by Alexander the Great in 332 BCE. Many Jews lived in two of the city's five quarters and comprised a large segment of the population. They could also worship in 
synagogues and lived near the Royal palace (Josephus, "Contra Ap." ii. 4;). They lived in areas where they could observe their laws by not being in continual contact with the pagan population (Schürer, 1912). Alexandria was composed of five districts, two of which were Jewish areas, since most of the inhabitants were Jews according to Philo ("In Flaccum", 8). It is evident that the Jews of Alexandria generally enjoyed much political freedom, in fact far more than others except for the Greeks. They kept their franchise as citizens and established an independent political community, living side by side with the heathen population and they could also keep their religious rituals, and regulate their own civil affairs- although at times they were monitored by royal representatives (Krauss, 1906). They enjoyed virtually the same rights as the Greeks ("In Flaccum",10). There were of course times when the Jews were severely persecuted such as during the reign of Caligula, when the Jews were termed "aliens and residents" ("In Flaccum",8). Their wealth enabled Jews to maintain some influence in Alexandrian society. The Ptolemies treated them in diverse ways, but they were generally well treated and many rose to prominence in the armed forces or served as tax collectors (Schürer, 1912). The city passed officially under Roman control in $80 \mathrm{BCE}$, according to the will of Ptolemy Alexander.

In Alexandria, the Jews fashioned a powerful base which unfortunately led to their persecution at times and many died during riots which occurred in the city when they failed to obey an imperial decree. Severe persecution broke out in $38 \mathrm{CE}$, when the Jewish king Agrippa went to Alexandria. The residences and shops of Jews were plundered and many Jews killed. and some synagogues were destroyed and Hadrian instructed his architect, Decriannus, to rebuild the ruined areas. From the time of Roman annexation and going forward, Alexandria regained its old affluence, and was an important granary for Rome under the Emperor Octavian. Throughout the Hellenistic era, the educated classes studied Greek literature in the schools, and read Homer, Plato, Aristotle, and the tragic poets and Stoics, and so many inhabitants of the city including the Jews were greatly influenced and became 'Greek thinkers'. Especially works of Plato and Aristotle, and to a lesser degree the Stoics, came to influences the Jews of Alexandria considerably. Consequently, many jews wrote history and philosophy and also dramatic poetry (Caird, 1904). Neo - Platonism thrived and it unquestionably influenced religious thinking as well. The Greeks acknowledged the divine unity that the Old Testament suggested and the Jews eventually acknowledged that the Greeks were in fact also teaching an idea of God. The philosophical status of Alexandria significantly influenced Pharisees and Sadducees. The Neoplatonist influence was prodigious and was "the germ out of which Christian theology sprang" (Caird, 1904). It tended to favour devoutness and was the harbinger of mysticism.

\section{The Great Library of Alexandria}

Alexandria has always been known for its celebrated Great Library of Alexandria which housed an estimated 400,000 to 900,000 books including an edifice which was linked through marble columns to the temple of the muses (Weber, 2010). Demetrius of Phalerum (350 BCE - 280 $\mathrm{BCE}$ ), an Athenian orator and statesman living in Alexandria who was prominent at the court of Ptolemy I, proposed the erection of the library to the ruler, who likely developed plans for the library, but it was not constructed until the reign of his son Ptolemy II Philadelphus. The library was eventually built in the Brucheion (Royal Quarter) of the city and was a part of the bigger research institution the Mouseion (Wiegand \& Davis, 2015). The Mouseion was dedicated to the famed nine goddesses of the arts and sciences known as the Muses. The muses were the daughters of Zeus, the chief god in the Greek Pantheon, and Mnemosyne, the goddess of memory (Murray, 2009). The Mouseion housed the Library and was additionally the lodgings of international scholars, poets, philosophers, and researchers, who, according to Strabo (64 BCE - 24 CE), a Greek geographer, philosopher, and historian, were 
provided with a hefty salary, free food and accommodation, and they were also exempted from paying any taxes.

The library soon became the most noteworthy one in existence in the ancient world. Thousands of papyrus scrolls were sourced for the library largely as a result of the Ptolemaic kings' decisive, efficient and well-funded policies for acquiring scrolls and other manuscripts (Schaff, 1910). In addition to its superb collection of scrolls, the Library of Alexandria had a series of Greek columns, a peripatos walk, a room for communal dining, a reading room, some meeting rooms, elaborate gardens, and even lecture halls, and all these formed a prototypical modern university campus (Lyons, 2011). The Serapeum built later, was a "daughter library" of Alexandria in the late fourth century CE and was undoubtedly the largest collection of books collected in the city of Alexandria (Watts, 2008). It was also a fully functioning temple, and contained classrooms in which philosophers taught and debated challenging topics of the day (Watts, 2008).

The complex also included an observatory as well as an anatomical laboratory that were second to none. There were also elaborate zoological and botanical gardens. It is not surprising that Alexandria became celebrated for the study of astronomy, medicine, mathematics and classical studies and Its university exhibited similar features and practices as those evident at the great school of Athens (Mahaffy, 1895). The milieu that developed favoured the promotion of Hellenic culture and learning and Alexandria soon became the hub of Hellenic cultural imperialism (Macleod, 2000). This culturally vibrant city then became home to numerous exiled Jews who settled in Alexandrias Jewish quarter, and they enriched the city's life through their intellectual scholars, merchants and skilled artisans from all the known world including Persia and Babylonia (Fogarty, 2004). In this environment, scholars and most people debated many aspects of philosophy and shared their views and this boded well since the Ptolemies desired to produce a repository of all knowledge in Alexandria (Casson, 2001). The large hall in the Library included rows of shelves for housing collections of papyrus scrolls that became known as bibliothekai from which scholars could obtain information from many different manuscripts and enhance their knowledge (Manguel, 2008). The groups of students who gathered to discuss issues and who lived at the Mouseion, were termed to be a synodos, "community" (Kennedy, 1999). The earliest identified enduring source of material on the founding of the Library of Alexandria is the pseudepigraphic Letter of Aristeas, likely composed between 180 BCE and 145 BCE (Lindberg, 1980).

In this Hellenistic age, the Greek language became the international language for the eastern Mediterranean and beyond. It became the chosen language for trade purposes, and especially education and writing. Alexandria's prestige grew as a place of earning the city library collected and accumulate information from the Greeks as well as the more ancient kingdoms of the Near East. Scholars, who sought to be leaders in their places of origin were provided with practical support in matters relating to effective and efficient ruling and governing in their various kingdoms (Fox, 1986). It was in Alexandria that Egyptians, Greeks and Jews socialized with eastern mystic thinkers to advance a novel civilisation. In this environment, there was for the most part, much academic freedom and tolerance of otherness.

In the second century BCE, the Old Testament which was originally in Hebrew and Aramaic, was translated into Greek in Alexandria to accommodate the Greek-speaking Jewry (Rajak, 2009). The production of the Greek Old Testament was very significant for the Christian Church as well as Judaism. It contained about twelve writings not contained in the Hebrew scriptures, and without the Septuagint, Judaism would have battled to survive amongst the Jews of the Diaspora. The Septuagint was also the Bible of the Christians (Price, 1971). A 
collection of books termed the Apocrypha (200 BCE - $100 \mathrm{CE}$ ) were added to the Septuagint but were not part of the Hebrew Old Testament.

The translation that emerged was termed the Septuagint. Concerning the Pentateuch in the Septuagint, a letter by Aristeas states that the librarian in Alexandria requested King Ptolemy II Philadelphus (284-247 BCE) to demand from the High Priest Eleazar of Jerusalem, that experienced translators be used to translate the Torah in Greek (Tcherikover, 1958). Thus, Aristeas and 71 other translators were sent to the island of Pharos and they worked there for 72 days to complete the work. The task was completed in 70 days, thus the name Septuagint (derived from septuaginta, the Latin word for 70) (Joosten, 2010). Eventually the Church Fathers used the term to apply to apply to the entire Old Testament, and it was the Bible of early Christians. The Library of Alexandria was not associated with any specific philosophical school, consequently, scholars who studied there had considerable freedom but were ultimately subject to the authority of the king (MacLeod, 2000).

Many great scholars emerged from Alexandria including the inventor Archimedes who invented the Archimedes' screw, a water pump, and this while he was a student at the Library of Alexandria (Staikos, 2000). Eratosthenes, the first person to promote geography as a scientific discipline and the man who produced a map of the whole known world, did so using information taken from sources held in the Library. This also included accounts of Alexander the Great's campaigns in India and additionally reports written by Ptolemaic elephant-hunting expeditions along the East African coast (Montana, 2015; Berti \& Costa, 2010). Aristophanes of Byzantium (257-180 BCE) was the fourth head librarian in Alexandria and he opened forged a highly established phase of the history of the Library of Alexandria, so much so that literary criticism reached its climax and began to lead the Library's scholarly outputs (Dickey, 2007; Olesen-Bagneux, 2014).

\section{Enter Christianity}

Numerous Hellenists who were Christians moved to Alexandria after the stoning of the protomartyr Stephen (Fogarty 2004). Christianity thus developed alongside Judaism in the city. These Christians operated as missionaries amongst the Jews and proselytized many of them. They initially met in 'house-churches' (Pearson, 1986). The blend of Jewish views and the new acceptance in Jesus, made it possible for the early supporters of Jesus to observe Judaistic teachings as well as those concerning Jesus, particularly in the 1st century and the beginning of the 2 nd century CE in Alexandria (Oliver \& Madise, 2014). In Daniel Chapter 11 we find reference to the Ptolemies of Alexandria and their spouses and in Acts 18: 24 there is reference to an orator who from Alexandria. John's gospel is also considered to be a discourse based on Alexandrian philosophy as were many New Testament writings. In Luke 27 and 28, Luke mentions that he and Paul sailed in a ship of Alexandria while the protomartyr Stephen was involved in debates in the synagogues of Alexandria Mark the Evangelist settled in Alexandria and this later developed into the Orthodox Church and also the Coptic Church (Fogarty, 2004).

\section{The Gnostics}

Alexandria in a sense equipped the Hebrews to become more amenable of the Christian gospel of universal acceptance. The first Christians in Alexandria were also undoubtedly influenced by all the cults and philosophies that were part and parcel of Hellenic culture and eventually Roman influence in the city. Alexandrian Christianity had its roots in Judaism but during Hadrian's rule, "Walter Bauer (1971) had the view that the original and most dominant form of Christianity in Alexandria until the time of Bishop Demetrius (189-231 CE) was 'heretical' and, specifically, Gnostic, as Gnostic teachers such as Basilides, Valentinus and 
Carpocrates were active in the city...the traditional watershed in Jewish and Christian Alexandria, the living contacts with Judaism seem to have vanished thereafter (Vrettos, 2001)" (Oliver \& Madise, 2014). The Gnostic movement developed and it absorbed a number of features from Judaism but gradually became syncretistic in orientation similar to many popular religions and even the philosophies of the Hellenistic Age in which Greek and Oriental thought merged (Price, 1971). The main characteristic of the pre-Gnostic world view was its radical dualism in which God, the unknown Father was supramundane and totally alien to anything remotely human and the imperfect world of mankind was dominated by lower powers such as demons, spirits etc. "... around and above man's world is a system of spheres or aeons-the pleroma which is the abode of the invisible spirits" (Price, 1971). Man belongs to the lowest order of beings but in the bodies of elect men an immortal divine spark was believed to exist and could be set free through gnosis, the knowledge of divine mysteries. And so the Gnostic in Alexandria taught that if a person knows what he is and from where he comes he can find his way home because he knows the nature of the world and the powers that rule it and has the potential to overcome these powers (Dodd, 1953).

\section{The Didaskaleion}

By the 2nd century, most people residing in Alexandria, other than Egyptians, were Jews. After proselytizing and missionary activities, the number of Christians grew, resulting in the establishment of the Didaskaleion. This was a Catechetical School which was established to counter the pagan philosophical schools. Mark the Evangelist founded the School in the early 40s CE. and a large number of Hellenistic Jews like Philo oversaw the Didaskaleion.

Many student arrived from the Mediterranean region. The heads of the School were Greektrained, and thus applied Hellenistic principles and taught Greek philosophy, and they gradually departed from their Jewish customs (Fogarty, 2004). The Didaskaleion became an important centre for holy sciences and the history of Christianity. and developed and applied Christian theology, and also the allegorical method of Biblical exegesis (Enslin, 1954). There were many important personalities residing and serving in Alexandria, such as Pantaenus, Dionysius, Gregory, Eusebius, Athanasius and Didymus. However two of heads of the school are highlighted in this article as prominent personalities including Clement and Origen who were exceptionally gifted theologians who paved the way for the Catechetical School in Alexandria and the Egyptian version of Christianity to spread far and wide. People are considered to be icons of the Imageo Dei and as such need to exert themselves so as to serve humanity as both Clement and Origen aspired to do throughout their lives as exemplary warriors of God (Nicolaides 2014).

Clement of Alexandria (150 CE - $216 \mathrm{CE}$ ), was born to a wealthy pagan family in Athens in the middle of the second century. He was well travelled and according to Stromateis 1.2 he was educated under an assortment of teachers who took him from Greece to Sicily and then to Egypt, where his career as a student of Christian philosophy took root after meeting Pantaenus (180), who was the headmaster of the Catechetical school in Alexandria. Clement, also known as Titus Flavius Clemens, soon became an eminent teacher in the Didaskaleion and he amalgamated Greek philosophical traditions with Christian canon and developed what later became known as Christian Platonism. He united albeit to an extent, Greek philosophy with Christian teachings and attracted a large number of educated pagans to the Church. Clement was converted to Christianity by his last teacher, Pantaenus who was allegedly a former Stoic philosopher and the first recorded head of the Christian Catechetical School at Alexandria. Clement eventually succeeded his teacher as Head of the School about $180 \mathrm{CE}$. Clement is regarded as the father of the Christian philosophy in Alexandria and was essentially the founder of formalised Christianity. Schaff (1885) speaking of Clement stated "that man of 
genius who introduced Christianity to itself, as reflected in the burnished mirror of his intellect". The principal point of his work revolved around training and teaching which he considered to be essential for sound Christian upbringing and later life (Oliver, 2017).

The most important of his surviving works is a trilogy comprising the Protreptikos ("Exhortation"), the Paidagōgos ("Instructor"), and the Strōmateis ("Miscellanies"). The most significant component of Clement's theology was his belief that philosophy is as divine a groundwork for the gospel as the law and the prophets of the Old Testament (cf. Stromateis $1.5,20)$. His surviving works include a tract on the use of wealth, A Discourse Concerning the Salvation of Rich Men; a moral tract, Exhortation to Patience; or, Address to the Newly Baptized; a collection of sayings by Theodotus, a follower of Valentinus (a leading Alexandrian gnostic), with commentary by Clement, Excerpta ex Theodoto; the Eclogae Propheticae (or Extracts), in the form of notes; and a few fragments of his biblical commentary Hypotyposeis (Outlines).

In his work Paedagogus, Clement talks to the people who are early converts to Christianity and demonstrate sound Christian morals and manners (Oliver, 2017; Barrett, 2011). This solid work served as a guide for the catechumens to build their character and live a Christian life. Clement argued that one's faith was the basis of salvation, but he also claimed that faith was the basis of gnōsis, a spiritual and mystical knowledge. Enslin asserts that Clement worked silently and efficiently to guide the intellectually undisciplined Christian movement to assume a decent standing among especially the educated in Alexandria (Enslin,1954; Oliver, 2017). Schaff correspondingly holds Clement in very high regard as the founder of Christian literature, after Justin and Irenaeus (Schaff 1885). He wrote on moral theology and was an originator of the Alexandrian Christian theology through his numerous scholarly works which set the tone for later Christian theology (Van den Hoek, 1997; Osborne, 1994). Clement's views paved the way for the curriculum of the Catechetical School which was later under Origen to evolve into the basis of the medieval quadrivium and trivium (the liberal arts) (Potter, 1715). This approach was initially frowned upon by some uneducated orthodox Christians of Alexandria. Under Demetrius, the bishop of Alexandria (189 CE), they imparted a legalistic doctrine of salvation and preached that a Christian could only be saved by faith (pistis). The only way to union with God (theosis) for Clement was the Church's way. Clement also mentions the angelic host as being important entities in one's spiritual life, "..the seven first Angels who have the greatest of power"(Clement the Alexandrian, Stromata, 6)

The faith of the baptized Christian encompasses all the basics of the highest knowledge and it is through the Holy Eucharist that the believer is united with the Logos and the Holy Spirit, and made a partaker of incorruptibility. The Holy Eucharist is by far the very oldest practice of Christian Worship as practiced in the Early Church (Nicolaides, 2009). In the Didache, a text of the early Church written in the first century, believers thank God "for the knowledge and faith and immortality which you have made known to us through Jesus your Son" (Didache 9:3). Clement asserted very clearly, "...the devil tempts us knowing who we are..." and according to our weaknesses he realises that he assaults us "...not knowing if we will resist..." and not knowing the results of his attacks (Clement, Stromata, 4, 12). In considering the notion of apokatastasis, or "restoration," Clement was the first Christian writer to mention the fire of hell as a purifying fire, a "wise fire that penetrates the soul" (Stromaties 7.6). So the wrath of God was understood by Clement as being corrective, even therapeutic: "God does not take vengeance, which is the requital of evil for evil, but he chastises for the benefit of the chastised" (Stromateis 7.16).

Cyril of Alexandria stated that the Angels know "...that God is the only One Who knows the secrets of men's hearts" (John, book II). The Alexandrian Fathers all accepted the idea of 
the lower Orders of Angels being raised to higher Orders by their perfection in Holiness as indeed all humans can, which in a sense aligned with Greek philosophy (Clement the Alexandrian, in B, v. 8, p. 348). Clement taught that The Divine Logos enlightened the souls of men from the beginning and it taught the Jews through Moses and also the prophets, and it also awakened the Greek philosophers, and gave them philosophy as their guide to a life of morality and righteousness. The object of Gnosis is not entirely God Himself but rather the Divine Logos. According to Clement, God in Himself is incomprehensible. We should not think of Him in terms of any name since His very essence becomes knowable only in His image and instrument, the Logos. Clement viewed the Logos as the universal world-forming and regulating reason and power, and it was thus one with God according to His immanence in the world. But equally, the Logos is the Son, personally different from God and secondary to $\mathrm{Him}$, who, as He first gave us as creator the natural life, so He has at last manifested in Christ as our teacher so as to afford us the opportunity for eternal life through works that are pleasing to the Father. Christ is consequently, according to Clement, a perfect manifestation of the universal principle of the true and good, which worked from the beginning in the world. To Origen, God is to be thought of as simple, unchangeable, perfect spirit, so far exalted above all finite beings that we are never able fully to know Him. He has indeed so expressed His nature in the visible creation that a certain relative knowledge is to be gained from it, as it is found in philosophers; but we Christians have learned to know God still better through the incarnate Logos (Spurlock, n.d.) and through the Holy Eucharist.

The Holy Eucharist is "... is the source of her life, the superlative act of her thanksgiving and of her sacrifice of praise to the creator God. The Holy Eucharist is the very core of Christian life, and the means by which each believer is nourished by God's grace and tender mercy. At the Divine Liturgy, the Church is continuously changed from a human community into the Body of Christ, the temple of the Holy Spirit, and the holy People of God" (Nicolaides, 2021). In addition "The term holy Eucharistia (thanksgiving) appears in the three synoptic gospels, Mark 14:22- 25, Matthew 26:26-29 and Luke 22:13-20, and it depicts Jesus as presiding over the Last Supper preceding his crucifixion" (Nicolaides, 2021). For at least twenty years, Clement was the intellectual leader, esteemed theologian, Apologist, and polemicist, of the Alexandrian Christian community (Chadwick, 1998). The Holy Fathers of the Orthodox Church in Alexandria all accepted that the forgiveness of sins is given equally to all and of the communion of the Holy Spirit as providing gifts according to the faith of each person. The increase and progress in the Newness of Holy Life made by believers greatly depends on the struggle of each individual person (Romans 11:16). The Grace of God, which is granted in Justification, creates not only simple psychological but real ontological alteration in man. We are not only considered merely Just by God, we turn out to be Just and receive Power to live according to Christ and this the message they imparted to adherents (Leeming, Principles, p. 4).

Origen (185 CE - $254 \mathrm{CE}$ ) also known as Origen Adamantius, taught in the Catechetical School where he followed in Clement's footsteps. He composed the seminal work of Christian Neoplatonism, which his treatise On First Principles. He understood scripture metaphorically and taught a doctrine of universal salvation in which all could be atoned with God (Balthasar, 1984). His method in reading and interpreting of the Holy Scriptures was fashioned by his understanding of their nature as the personification of the Logos. His approach was further molded by his understanding of God, the Logos, the world as God's creation and the goal of the history of Creation. Origen emphasised the critical importance of human will and freedom in the process of redemption (Decock, 2011). The purpose of Holy Scriptures is according to Origen, to address the readers and transform their lives (Crouzel, 1956). Origen referred to the Holy Trinity as the "Holy Trinity," "Eternal Trinity," "Primary Trinity," and "Worshipped 
Trinity." He believed that the Son of God is "the Word of God" and "God the Word." (Epiphanius, Heresy, 27, 28, 41). Third century Christians in Alexandria accepted teachings on Revelation for example, based the tendency of the church to interpret scripture allegorically and Origen's efforts in this regard and he was the creator of historical philosophy an expert of allegory. He sought to methodically organise the Old Testament. Through his efforts, a philosophy of the Christian faith was forged and this was a critical moment in the advance of Christian thinking (McGuckin, 2001; Wilken, 2013). For Origen the chief virtue is love of God, which is consequently the goal of the Christian paideia he clearly understood the Scriptures as the Christian version of this paideia (Decock, 2011). In many ways the primitive Christian faith became dogmatic theology due to the efforts of the Alexandrian Fathers.

\section{The Evangelist Mark - Founder of the Orthodox Church of Africa}

St. Mark the author of the Second Gospel was related to St Barnabas1 (Colossians 4: 10) and was clearly the key player in the Alexandrian Church which he founded (Joel, Chronographia), and ultimately became the initial Bishop of the Church in Alexandria (Eusebius, Church History, book II). In the Book of Acts, Mark the Apostle and Evangelist is cited as having an additional name, John (Acts 12:12, 25; 13:5, 13; 15:37). St. Luke the Evangelist was the first to refer to St. Mark (Acts 12:12). St Mark, thus had two names, "John" and "Mark," the first was his Jewish name and the last, his Roman name (Acts 12: 25). Mark became a disciple and "...interpreter..." (Eusebius, Church History, book I), of St. Peter (Eusebius, Church History, book III). St. Mark was born in Cyrene of Pentapolis and was the son of Aristoboulos and Mary. (Martyrdom of St Mark, in Migne, P.G., 115) and he may have been an Alexandrian Jew who lived with his family in Jerusalem .

In Acts 15:39, we read that he went to Cyprus with Barnabas after the Council of Jerusalem. and he also accompanied St. Paul and St. Barnabas during their first journey from Antioch to Perga of Pamphylia where he abandoned them and returned to Jerusalem.

St. Mark was a companion of St. Peter and wrote his Gospel based on the oral teachings of St Peter (Siskos, Organosis, ch. XXXIX). When he left Asia Minor, he disembarked at Cyrene, Pentapolis, where he was likely born. Mark preached and imparted his knowledge and in the

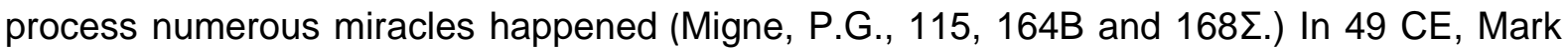
moved to Alexandria and founded the Church of Alexandria, and the Greek Orthodox Church of Alexandria as well the Coptic Church trace their roots to this event (Pearson, 1997; Polyzoides, 2014). Mark was the first bishop of Alexandria and he is considered to be the founder of Christianity in Africa (Bunson et al., 1998). The Gospel according to Mark was written prior $68 \mathrm{CE}$, which was the year Mark was martyred in Alexandria (Oden, 2011). The Gospel of Mark was written in Alexandria in about $64 \mathrm{CE}$, for Gentiles and those who were unfamiliar with Aramaic and Jewish customs in Palestine (Marxsen, 1969). He introduced the characters in the Gospel as people known to his audience and they were likely already Christians and he stresses the urgency of the mission of the Church to outsiders (Price, 1971). He provides the "good news" so as to confirm the faith of adherents and also to stress the seriousness of unbelief. Mainly amongst the Jews (Weiss, 1967). Mark taught that the theological meaning of the cross can only be understood by people person who have prepared themselves to renunciate the self and who are willing to offer a life of service and even suffering or martyrdom if need be (Weiss, 1967). St. Mark converted many Egyptians, Greeks, Jews and Romans to the Orthodox Christian Faith (Eusebius, Temporum, II).

St. Mark's acts and the Traditions associated with his evangelism to Christianity of Egypt, are preserved in the writings of his successors (Migne, P.G., 111, 889) and he established the Greek Orthodox Church of Alexandria shortly before his last collaboration with St Paul whom 
he met and assigned him to a special Mission to the Churches of Asia Minor. At the beginning of $63 \mathrm{CE}$, St. Mark returned to Egypt passing through Cyrene. Back in Alexandria, he was arrested during the celebration of pagan feasts honouring Serapis. He was tortured and dragged through the streets of Alexandria and he reposed the next day. Soon after his tomb was venerated by the faithful until some unscrupulous traders from Venice stole his relics and took them to their Adriatic city.

The history of the Greek Orthodox Patriarchate of Alexandria comprises some of the supreme fathers of the Church, particularly Athanasius and Cyril, who were patriarchs of Alexandria at the ecumenical councils of Nicaea and Ephesus respectively. In the last three decades much missionary effort has been enacted by the Popes and Patriarchs of Alexandria and all Africa Petros VII and his successor Theodoros II. The current Patriarch is also working assiduously to spread the Orthodox Christian faith throughout Africa. Numerous native clergy have been ordained and there are efforts to promote the use of local languages in the liturgical life of the church. Today, there are roughly 350,000 Eastern Orthodox Christians who constitute the Patriarchate of Alexandria in Egypt alone.

\section{Conclusion}

There is clearly no doubt Alexandria played a foremost role in the development of Christian theology during the time of the Early Church and was perhaps the most significant originator of the theology of Christianity in the Hellenized areas of north of Africa. The historical genesis of Alexandria is intensely associated with Alexander of Macedon and his genius in calling for the construction of a city east of the Nile delta. Remnants of the ancient Hellenic culture endure and can be detected in Alexandria up to the present time. There is no doubt that the famous Great Library of Alexandria was a fertile breeding ground for philosophers and clerics who promoted the Orthodox faith such as the Church Fathers or the early and influential theologians and writers in the Christian Church, particularly those of the first five centuries. These include inter alia Clement of Alexandria, Origen, Athanasius of Alexandria, Cyril of Alexandria, and the monastic Desert Fathers such as Anthony the Great and Pachomius.

The aspects addressed in this article relate more specifically to the importance of Alexandria as a cosmopolitan city in which the Christian faith flourished. After scrutinizing and surveying a range of works which provide useful information on Alexandria and its relevance to Christendom, it is relatively easy to conclude that the city has played an immense role in the promotion of early Christianity and still continues to have an impact on especially African Orthodox Christianity - it is truly a Laos tou Theou (Nicolaides, 2010). The Coptic Orthodox church which is Monophysitic in orientation, also endures to this day in Egypt and interestingly it still uses the Greek language in parts of its Coptic liturgical services.

\section{References}

Balthasar, H. U., von (1984). Origen: Spirit and fire: A thematic anthology of his writings, T \& T Clark, Edinburgh.

Barrett, N.C. (2011). The Alexandrian Catechetical School of Clement and Origen as a postmodern model for the contemporary church and theological academy, MA thesis, Department of Religion, Hardin-Simmons University.

Berti, M. \& Costa, V. (2010). La Biblioteca di Alessandria: storia di un paradiso perduto, Tivoli (Roma): Edizioni TORED.

Bunson, M., Bunson, M. \& Bunson, S. (1998). Our Sunday Visitor's Encyclopedia of Saints, Huntington, Indiana: Our Sunday Visitor Publishing Division. 
Caird, E. (1904). Evolution of Theology in the Greek Philosophers, Vol. II, Wipf \& Stock Publishers.

Casson, L. (2001). Libraries in the Ancient World, New Haven, Connecticut: Yale University Press.

Chadwick, H. (1998). Clement of Alexandria (AD 150-215), Routledge Encyclopedia of Philosophy, Taylor and Francis, [Available online at https://www.rep.routledge.com/articles/biographical/clement-of-alexandria-ad-150-215/v-1].

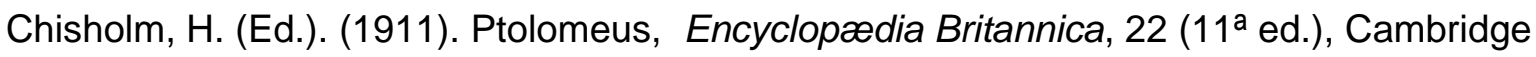
University Press.

Clayton Croy, N. (2006). 3 Maccabees: Septuagint Commentary Series, Leiden: Brill. pp. xiixiii

Clement the Alexandrian, Stromata, 4, 12, in B, v.8, p. 78.

Clement the Alexandrian, Stromata, 6, § 16, in B, v.8, p. 232

Crouzel, H. (1956). Theologie de l'image de Dieu chez Origne (Theology of the image of God in Origen), Editions Montaigne, Paris.

Cyril of Alexandria, To John, book II, ch. 1,in Migne, P.G.,73, 224

Decock, P. B. (2011). Origen of Alexandria: the study of the Scriptures as transformation of the readers into images of the God of love, HTS Theological Studies, 67(1).

Dickey, E. (2007). Ancient Greek Scholarship: A Guide to Finding, Reading, and Understanding Scholia, Commentaries, Lexica, and Grammatical Treatises from Their Beginnings to the Byzantine Period, Oxford, England: Oxford University Press.

Didache. (1970). In the Apostolic Fathers, translation by K. Lake.

Dodd, C.H. (1953). The Interpretation of the Fourth Gospel.

El-Abbadi, M. (1990). The Life and Fate of the Ancient Library of Alexandria, 2nd, illustrated ed., Unesco / UNDP.

Enslin, M.S. (1954). A Gentleman among the Fathers, Harvard Theological Review, 47(4), 213-241.

Epiphanius, Heresy, 27, 28, 4142, 51, in Migne, P.G., 41, 368, 377, 696, 888

Erskine, A. (1995). Greece \& Rome, 2nd Ser, Culture and Power in Ptolemaic Egypt: The Museum and Library of Alexandria, 42(1).

Eusebius, Temporum, II, in Migne, P.G., 19, 647, 648.

Eusebius, Church History, book I , in Migne, P.G., 19, 539.

Eusebius, Church History, book III, ch. XXXIX, in Migne, P.G., 20, 300B-C.

Eusebius, Church History, book II. in Migne, P.G., 19, 543c.

Eusebius, Church History, book III, ch. XXXIX, in Migne, P.G., 20, 300B-C.

Favard-Meeks, C. \& Meeks, D. (2000). The heir of the Delta, in Jacob, Christian, \& François de Polignac, eds. (1992/2000). Alexandria, third century BC: The knowledge of the world in a single city. Translated by Colin Clement. Alexandria: Harpocrates Publishing. 
Fogarty, M.E. (2004). Egyptian Christianity: An historical examination of the belief systems prevalent in Alexandria C.100 BCE - 400 CE, unpublished MPhil dissertation, Department of Ancient Near Eastern Studies, University of Stellenbosch.

Fox, R. L. (1986). 14: Hellenistic Culture and Literature, in Boardman, J., Griffin, J., \& Murray, O. (eds.), The Oxford History of the Classical World, Oxford, England: Oxford University Press.

Joel, Chronographia, in Migne, P.G., 139, 248C.

Spurlock, S. (n.d.). Philosophy and Development of Religion, vol. 2. University of Edinburgh, Gifford Lectures.

Harris, W.V. \& Ruffini, G. (eds.). (2004). Ancient Alexandria Between Egypt and Greece. Columbia Studies in the Classical Tradition, Vol. XXVI, Leiden \& Boston: Brill.

Hirata, A. (2008). Die Generalklausel zur Hybris in der alexandrinischen Dikaiomata, Savigny Zeitschrift 125, 675-681.

Hölbl, G. (2001). A History of the Ptolemaic Empire, London \& New York: Routledge.

Joosten, J. (2010). The Aramaic Background of the Seventy: Language, Culture and History, Bulletin of the International Organization for Septuagint and Cognate Studies, 43, 53-72.

Josephus, Flavius. Contra Ap." ii. 4, Jewish Encyclopaedia. [Available online at https://www.jewishencyclopedia.com/articles/1171-alexandria-egypt-ancient/]

Kennedy, G. (1999). The Cambridge History of Literary Criticism: Classical Criticism, New York: University of Cambridge Press.

Krauss, S. (1906). Alabarch, Jewish Encyclopedia, New York: Funk \& Wagnalls.

Kuiper, K. (n.d.). Serapis Greco-Egyptian deity, The Editors of Encyclopaedia Britannica, [Available online at https://www.britannica.com/topic/Serapis]

Leeming, B. (1955). Principles of Sacramental Theology, A Catholic Commentary on Holy Scripture, London.

Lindberg, D.C. (1980). Science in the Middle Ages, University of Chicago Press.

Lyons, M. (2011). Books: A Living History, Los Angeles, CA: Getty Publications.

MacLeod, R. (2000), Introduction: Alexandria in History and Myth, in MacLeod, Roy (ed.), The Library of Alexandria: Centre of Learning in the Ancient World, New York City, New York and London, England: I.B. Tauris Publishers.

Mahaffy, J. P. (1895). Empire of the Ptolemies, London and New York : Macmillan and Co.

Manguel, A. (2008). The Library at Night, New Haven: Yale University Press.

Martyrdom of St Mark, in Migne, P.G., 115, 164-165, 168-169.

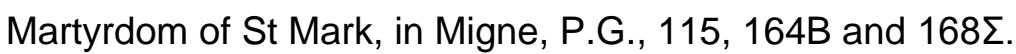


Marxsen, W. (1969). Mark the Evangelist, trans. R. Harrisville.

McGuckin, J. A. (2001). Origen as Literary Critic in the Alexandrian Tradition, 121-37 in Vol. 1 of Origeniana octava: Origen and the Alexandrian Tradition, Papers of the 8th International Origen Congress (Pisa, 27-31 August 2001).

Montana, F. (2015). Hellenistic Scholarship, in Montanari, Franco; Matthaios, Stephanos; Rengakos, Antonios (eds.), Brill's Companion to Ancient Greek Scholarship, 1, Leiden, The Netherlands and Boston, Massachusetts: Koninklijke Brill.

Murray, S. A. (2009). The library: An illustrated history, New York: Skyhorse Publishing.

Nicolaides, A. (2021). Investigating the Holy Eucharist and the term 'people of God' according to the Eastern Orthodox Church, Pharos Journal of Theology, Volume 102.

Nicolaides, A. (2014). The Seventh Ecumenical Council and the veneration of icons in Orthodoxy, Acta Theologica, 34(2), 77-93.

Nicolaides, A. (2010). The Laos tou Theou - an orthodox view of the 'people of God', HTS Teologiese Studies/Theological Studies, 66(1).

Nicolaides, A. (2009). The Significance of the Eucharist in Orthodoxy, Australian eJournal of Theology, Issue 13, Australian Catholic University.

Oden, T.C. (2011). The African Memory of Mark: Reassessing early church tradition, InterVarsity Press, Downers Grove, IL.

Olesen-Bagneux, O. B. (2014). The Memory Library: How the library in Hellenistic Alexandria worked, Knowledge Organization, 41(1), 3-13.

Oliver, W. H. (2017). Documents written by the heads of the Catechetical School in Alexandria: From Mark to Clement, Verbum et Ecclesia, 38(1), 1-11. [Available online at https://dx.doi.org/10.4102/ve.v38i1.1766]

Oliver, W. H. \& Madise, M. J.S. (2014). The formation of Christian theology in Alexandria, Verbum et Ecclesia, 35(1), 1-13.

Osborn, E. (1994). Arguments for faith in Clement of Alexandria, Vigiliae Christianae, 48, 124.

Pearson, B.A. (1986). Christians and Jews in first-century Alexandria, Harvard Theological Review, 79(1-3), 206-216.

Philo, (1855). In Flaccum, Vol. IV of The Works of Philo Judaeus, translated from the Greek by C. D. Yonge, B.A., London: Henry G. Bohn.

Polybius (1926). Polybius. The Histories. The Loeb Classical Library (in Ancient Greek, English, and Latin). Translated by Paton, W.R. London; New York: William Heinemann; G.P. Putnam's Sone. Volume V. Loeb Number L160; Books XVI-XXVII.

Polyzoides, A. J. (2014). Alexandria: City of Gifts and Sorrows: From Hellenistic Civilization to Multiethnic Metropolis, Sussex Academic Press.

Potter, J. (1715). Clementis Alexandrini opera quae extant omnia" , Oxford, 1715; Venice, 1757, reproduced in Migne, P.G. VIII, IX. 
Price, J. L. (1971). Interpreting the New Testament, Second Edition, Holt, Rinehart and Winston, Inc., Sydney,

Rajak, T. (2009). Translation and survival: the Greek Bible of the ancient Jewish Diaspora, Oxford \& New York: Oxford University Press.

Schaff, P. (1910). History of the Christian Church, Eerdmans, Grand Rapids.

Schaff, P. (ed.), (1885). Ante-Nicene Fathers. Vol. 2: Fathers of the second century: Hermas, Tatian, Athenagoras, Theophilus, and Clement of Alexandria (Entire), Christian Classics Ethereal Library, Grand Rapids, MI.

Schürer, E. (1912). Diaspora, Dictionary of the Bible - Extra Volume: Containing Articles, Indexes, and Maps, ed. James Hastings, New York: Charles Scribner's Sons.

Staikos, K. Sp. (2000). The Great Libraries: From Antiquity to the Renaissance, Newcastle, Delaware and London, England: Oak Knoll Press \& The British Library.

Stark, R. (1997). The rise of Christianity, Princeton: Princeton University Press.

Tcherikover, V. (1958). The Ideology of the Letter of Aristeas, Harvard Theological Review, 51(2) (April 1958).

Theodore, J. (2016). The Modern Cultural Myth of the Decline and Fall of the Roman Empire, Manchester, England: Palgrave, Macmillan.

Van den Hoek, A. (1997). 'The 'Catechetical' School of Early Christian Alexandria and its Philonic heritage, Harvard Theological Review, 90(1), 59-87.

Vrettos, T. (2001). Alexandria: City of the Western mind, The Free Press, New York.

Watts, E. J. (2008). City and School in Late Antique Athens and Alexandria, Berkeley and Los Angeles, University of California Press: California.

Weber, G. (2010). Alexandreia und das ptolemäische Ägypten: Kulturbegegnungen in hellenistischer Zeit, Berlin: Verlag Antike,

Weiss, J. (1959). Earliest Christianity, trans. (Ed.)., F. C. Grant.

Wiegand, W. A. \& Davis, D. G. (Jr.). (2015). Encyclopedia of Library History, New York and London: Routledge.

Wilken, R. L. (2013). A Learned Faith: Origen of Alexandria, The First Thousand Years: A Global History of Christianity, Choice Reviews Online. 50. New Haven and London: Yale University Press. 